\title{
CASE STUDY ON CONSERVATION OF MUSEUM
}

\author{
S. Sundari \\ Assistant Professor \\ Department of Tourism and Travel Management
}

\begin{abstract}
This entire topic deals with the conservation, preservation deterioration and restoration of artifacts. The vulnerability to damage and their control measures also differ. Depending upon the type of treatment to be given to the objects, they can be classified as metal, organic, inorganic and paintings.
\end{abstract}

Keywords - Conservation, metal, ceramics, glass etc.

\section{INTRODUCTION}

A museum is considered as a temple of the muses-mousein (Greek) up to $15^{\text {th }}$ Century AD. In the $15^{\text {th }}$ Century museum was considered as a building used for the storage and exhibition of historic and natural objects. According to the ICOM, "Museum is a non-profit making permanent institution in the services of the society and of its development and open to the public, which acquires, conserves, researches, communicates and exhibits for purposes of material evidence of man and his environment". In Venice, for the first time museum was made available for visitors in $1523 \mathrm{AD}$. In $1625 \mathrm{AD}$ a collection of biological specimens and artifacts by John Tradescant and his son at Lamberth, London was made available for public. In India the first museum was started at Kolkata (Calcutta) in the beginning of 15th century.

\section{CLASSIFICATION OF OBJECTS}

Any object representing culture, art etc. preserved in a museum qualifies itself to be a museum objects. They vary from one to the other due to nature, type, property etc. Their vulnerability to damage and their control measures also differ. Depending upon the type of treatment to be given to the objects, they can be classified as follows:

1. Metals

2. Organic objects

3. In-organic objects and

4. Paintings

\section{Metals}

Metals and alloys form a major portion of museum collections. They are bronze icons, bells, vessels, weapons, jewelleries, coins etc. they are affected by corrosion. The corrosion products should be removed and stabilized avoiding further corrosion.

\section{Organic Objects}

Materials derived from living organisms are organic objects. Wooden objects like temple cars, clothes, doors, vahanas, palm leaves, leather objects etc, are prone to climatic changes. The environment should be stable and the objects should be attended to carefully, as insects also at large easily affect them.

\section{In-Organic Objects}

Inorganic materials are very stable. They are complex in nature. Stone pillars, sculptures, inscriptions, terracotta glass objects, ceramics etc, are some of the inorganic materials. They are mostly exposed to the atmosphere and are affected both by rain and weathering takes place. They should be treated and preserved.

\section{Paintings}

The paintings are multi-layered and therefore they require special study and treatment. There are various types of paintings like murals, oil paintings, water colour paintings, panel paintings, glass paintings, miniatures in paper etc.

\section{METAL OBJECTS}

$\begin{array}{ll}\text { i) } & \text { Metal Objects } \\ \text { ii) } & \text { Copper Objects } \\ \text { iii) } & \text { Gold Objects } \\ \text { iv) } & \text { Silver Objects } \\ \text { v) } & \text { Lead Objects } \\ \text { vi) } & \text { Iron Objects }\end{array}$

i) Metal Objects

iii) Gold Objects

iv) Silver Objects

vi) Iron Objects 


\section{International Journal of Engineering Applied Sciences and Technology, 2019 Vol. 4, Issue 5, ISSN No. 2455-2143, Pages 390-400 \\ Published Online September 2019 in IJEAST (http://www.ijeast.com)}

\section{FACTORS AFFECTING METALS}

Metals as materials have more strength and flexibility of manipulation than stone or clay or wooden objects, when it comes to chemical stability they (except gold and silver) fall far short of the latter. They are susceptible to many factors, which bring about their deterioration and the ultimate transformation into forms (ores/minerals) in which forms they occur in nature. Corrosion is the menace that the Conservator faces with metallic antiquities.

The deteriorating factors affecting metallic antiquities are:

1) Humidity/Temperature,

2) Air/Contaminated air and

3) Lack of maintenance.

\section{Humidity/Temperature}

Humidity is the measure of moisture content in air/soil. Humidity brings about deleterious effects on metallic antiquities. Under excessive wet conditions, corrosion on metals is encouraged. In damp and hot conditions bacterial and fungal growth facilitate further corrosion.

\section{Air Pollutants}

Oxygen, oxides of sulphur, carbon and nitrogen, hydrogen sulphide, etc.Present in the air adversely affect the metal objects forming oxides, carbonates, sulphates, sulphides, nitrides and other complex corrosion products.

\section{Lack of Maintenance}

Prolonged exposure to an un-optimized temperature, humidity etc, negligence, mishandling, improper package, transportation and direction during transit etc, also affect metallic antiquities to a great extent.

\section{CONSERVATION OF METAL OBJECTS}

The two main objectives of conservation of metals are,

i) Removal of corrosion products and

ii) Arresting further corrosion.

\section{Removal of Corrosion Products}

Corrosion products on metallic artifact should be thoroughly removed in order to prevent further corrosion of the artifacts.
Removal of corrosion products can be effected either by

\section{Physical Method}

Corrosion products along with the siliceous materials can conveniently be removed physically by simple mechanical tools such as pin, scalpel, chisel, hammer, mechanically operated vibro-tool etc. The areas exposed after the unwanted corrosion products thus removed are given a final rub with fine emery sheet to bring out the inner patina can also act as a protective coat. Mechanical means in that the former methods do not introduce or leave behind any additional chemicals or products of chemical changes on the metal artifacts.

\section{Chemical Method}

Chemicals, which can dissolve or form soluble complex with the corrosion products are used to remove the deleterious materials from the objects. Only mild chemicals and very dilute solutions are used to remove the corrosion products without affecting the metal beneath. If chlorides are present in bronze antiquities, the antiquities are soaked for few weeks in a solution of sodium sesquicarbonate (equal proportions of sodium carbonate and bicarbonate), by this procedure the metallic artefacts are protected and preserved.

\section{Electrolytic Brushing}

In case of large sized, non-transportable bronze objects a localized treatment of a slightly modified electrolytic method is resorted with good success. Electrolytic brushing cleans the bronze icons, which are affected by weeping. Since the holes found at the weeping spots are just able to take the finest needle of a syringe, the liquid collected in the holes is first syringed out. When numerous holes are present in the icon, the surface of the affected object is poulticed with moist neutral paper pulp and the same removed when dry. This is repeated till the paper pulp gives a negative test for chloride.

\section{Intensive Washing}

Intensive washing is the last step but definitely and not the least importance in conservation of artefacts. Unless the treated objects are washed completely free from the chemicals left behind on the objects, they will once again react with metal and the corrosion cycle will be repeated again. Therefore washing should be intensive and thorough in the final stages especially with methods involving 


\section{International Journal of Engineering Applied Sciences and Technology, 2019 Vol. 4, Issue 5, ISSN No. 2455-2143, Pages 390-400 \\ Published Online September 2019 in IJEAST (http://www.ijeast.com)}

chemical treatments. The last residual salts in the treated objects in distilled water or the process may be speeded up by using hot water. This process may be repeated to ensure complete removal of chemicals.

\section{Arresting Corrosion}

\section{Stabilization of Highly Corroded Objects}

In most of the excavated and treasure-trove objects, it is seen that the corrosion has proceeded to an extreme stage where very little metal is left intact. In such cases, objects can best be conserved by stabilizing the corrosion products formed. Spots of bronze disease over protective layer be mechanically removed. The pits found are the filled with a fine paste of silver oxide (in alcohol/water). One of the methods of preventing bronze disease in antiquities is to maintain the antiquity in dry atmosphere. Under these conditions the spreading of further corrosion is arrested. Even wood emanates some acid fumes and therefore silver objects displayed inside the cases are affected. Zinc oxide globules are kept in the cases to absorb the hydrogen sulphide vapours thereby can avoid corrosion.

\section{INORGANIC OBJECTS}

$\begin{array}{ll}\text { i) } & \text { Stone Objects } \\ \text { ii) } & \text { Ceramics } \\ \text { iii) } & \text { Stucco Objects } \\ \text { iv) } & \text { Glass and Glazes. }\end{array}$

\section{STONE OBJECTS}

Stone is a position of rock. Rocks and minerals are in abundant and are consisted with silicate units. The main cations are sodium, calcium, magnesium and aluminiun. A linear polymer-like structure of silicate units from the basis of fibrous minerals such as asbestos. A planer structure in which silicate units are linked in two dimensions give rise to soft, slippery minerals, such as talc, mica and soapstone. A three dimentional framework silicate, as in quartz and feldspars, results in extremely strong solid.

There are various types of rocks such as igneous, metamorphic and sedimentary rocks. Igneous rocks like granite and basalt are those which were formed by the cooling of volcanic lava. Sedimentary rocks like sandstones and limestone were deposited at the beds of lakes and ponds. Metamorphic rocks, for example marble were formed by the metamorphosis of either igneous or sedimentary rocks into a new form on account of pressure or heat or some other geological change.

\section{VIII.DETERIORATION OF STONE}

Excavated stone objects are much affected by crystallization of salts, which are absorbed with in stone. Since salts are deposited in cavities near the surface, they can impose strains great enough to cause complete disintegration of surface features such as ornamentation. Outdoor stone objects suffer the damages due to acid rain. Deterioration also occurs due to the growth of algae, fungi, moss, lichen and other micro- vegetation. After dying they appear black. Droppings of insects and birds also affect the stone objects and monuments.

\section{Visual Examination}

In order to decide on the strategy of conservation, stone objects should be studied and examined very carefully. Using a magnifier the condition of the stone should be studied. The surface should be watched for the presence of deposits like crust, salts, mould, dirt, pigments, voids, flaking, powdering etc. The hardness may be tested. The alteration products may be analysed by spot tests and by x-ray diffraction studies. Soluble salts like chlorides, nitrates, sulphates should be removed immediately or they will damage the stone.

\section{CONSERVATION OF STONE OBJECTS}

Most of the deteriorations on stone are due to water. The main job is to remove the unwanted dirt and salts from the objects, protecting the surface with water repelling material, and consolidating the surface.

\section{Removal of Dirt}

Stone sculptures often accumulate dust, dirt and stains. Loose dust can easily be brushed off. Pure water with detergent is use to remove the dirt accretions. Stains of grease, oil, wax or paint can be cleaned with suitable organic solvents like toluene, acetone, benzene etc, or their mixtures. If the oily grease is deeply rooted, the grease can be removed by applying paper pulp on the surface of stone where the accretions are found and covered with polymer sheet to avoid the escape of solvent and removing the paper pulp after an hour. The grease is removed step by step and the real colour of the stone is regained after repeated 


\section{International Journal of Engineering Applied Sciences and Technology, 2019 Vol. 4, Issue 5, ISSN No. 2455-2143, Pages 390-400 \\ Published Online September 2019 in IJEAST (http://www.ijeast.com)}

applications of the paper pulp with the suitable solvent.

\section{Removal of Salt}

Salts that have migrated into the stone are to be removed along with efflorescent deposits on the surface without causing further damage. Smaller objects may be immersed in salt free water. A poultice is applied to remove the salts. Porous materials such as cotton, wool, paper pulp are used as poultices.

\section{Removal of Biological Accretions}

Deposits of moss or algae not only make them to appear patchy, green or black in colour but also produce pits in the surface of the stone, thereby weakening the structure. Cotton pads dipped in the solution and kept on the affected area for 15 minutes, brushing and washing will remove the growth.

\section{CERAMICS}

Early man started using the naturally available materials for his daily use. Clay was certainly among man's earliest discoveries of natural materials adaptable to his needs. Ceramics is the general term for an object made out of clay like pottery, porcelain and earthenware. Ceramic materials were in vogue in the sites of ancient culture throughout the world. The red and black wares, polished wares, megalithic potteries and the modern glazed wares are familiar to India.

\section{DETERIORATION OF CERAMICS}

Most of the ceramic objects are excavated and are saturated with both insoluble and soluble salts of the soil, if they are unglazed or broken. Unbaked clay objects are very fragile and are easily affected by water. Even high humidity will make it to disintegrate. Unbaked clay objects inherit severe vibration or shock. Baked clay objects are also vulnerable to shock and severe vibration. Rough unfired clay objects as well as weathered baked clay objects are easily accumulated with dust, which becomes dirt with moisture and is difficult to remove the dirt. Ceramic objects get stained very easily. This may be affected because of the iron nails and their rusting. Labeling with adhesive labels also make stain on the objects. Since clay objects are fragile, they are vulnerable to abrasion and scratches. Applied decoration such as gold leaf or unfired pigments might be poorly fixed.

\section{CONSERVATION OF CERAMICS}

Unbaked clay objects are prone to damage due to water, moisture, shock, vibration etc, care should be taken to conserve them. Clay objects if once baked then they may be washed to remove the salts present in them. The excavated baked objects may be soaked in running water and the salts present are leached out by this process. Any stain found on them may be removed by using solvents like acetone, benzene etc, after they dried.

\section{Mending of Ceramics}

Most of the excavated ceramics are found broken and portions are not found. The broken pieces have to be mended. It requires great patience. It is always better to number the pieces and put them together. The broken edges should be cleaned with a soft brush and then with suitable solvents. The acrylic resin should be applied at the broken edges and joined. The joints should be filled with filler like acrylic resin and matched with acrylic colours.

\section{Storage}

For most of the ceramic objects the relative humidity and temperature levels are not critical but these two factors should never be allowed to fluctuate drastically. In case the objects have soluble salts then the relative humidity should be around $5 \%$ and the temperature around 19 degrees Celsius. If the ceramic is painted with light sensitive pigments, the light level should not be above 150 lux.

\section{XIII.STUCCO OBJECTS}

Stucco objects are constructed out of fired brick and lime mortar. They have the quality of both fired brick and lime mortar. These objects are normally found in middle aged temples and they are found white washed and details would have been almost lost. Some of the stucco figures are found painted and are brilliant.

\section{XIV.DETERIORATION AND THEIR CAUSES}

Various causes of decay found in the secco figures are cracking, flaking. Salt action, powdering, physical damage etc. These can be avoided when the objects are free from moisture, abrasion, etc. The stucco figures found in the towers (gopuras) are normally found painted. But due to age, they turn black as they are exposed to the open air where moss, lichen etc, react with the stucco during the monsoon. 


\section{International Journal of Engineering Applied Sciences and Technology, 2019 Vol. 4, Issue 5, ISSN No. 2455-2143, Pages 390-400 \\ Published Online September 2019 in IJEAST (http://www.ijeast.com)}

\section{CONTROL AND CONSERVATION MEASURES}

Stucco figures are not many in museums. But the damages found on the stucco figures should be set right. The soluble salts may be removed by poulticing. The loose broken pieces and ends may be fixed to the main object by means of a $10-15 \%$ solution of poly vinyl acetate dissolved in toluene. The black accretion may be clean with the help of dilute ammonia.

\section{XVI.GLASS AND GLAZES}

The use of glass dates back to 3000 B.C. Mesopotamians, probably were the first user of glass. Ancient glasses were found to have either magnesium or aluminum. Those glasses which contained aluminum, are much durable than the other. Pottery and mud bricks were also glazed to make them impermeable to water. The glazes used were similar in composition to glass artifacts although often made to cover defects on the surface of the substrate. For similar reasons metals were sometimes coated with coloured enamels, which were also glossy in nature. Liquid glass is cooled below the melting point too rapidly to crystallize. Glass is a super cooled liquid. The characteristic properties of glass are its transparency, hardness and rigidity at ordinary temperatures obtained with a capacity for plastic working at elevated temperatures.

\section{DEFECTS IN GLASS}

Glass must be preserved well in a dry climate. The glass may lose its transparency and become cloudy or crizzled, which is commonly called as glass disease. When moisture is in prolonged contact with glass the cations such as sodium, potassium and calcium are leached out and replaced byhydrogen and a layer of alkali metal hydroxides such as sodium, potassiumand calcium hydroxides are formed at the surface of the glass. They are very hygroscopic and absorb more water. If left untreated the glass may become so badly crizzled that small flakes break off when the glass is handled.

\section{CONSERVATION OF GLASS}

The deterioration of glass can be stopped by avoiding contact of water with glass. The soluble alkali salts are washed with water, dried with rectified spirit, acetone or ether and stored in low humidity cases keeping silica gel. Broken glass vessels are repaired by using cellulose nitrate like Durafix which does not shrink or undergo discolouration. In the restoration of glass in filling the missing parts thermoplastic, methacrylate resins such as Perspex are often used. The most successful results are with certain acrylic and polyester resins, as they are transparent, and not yellow, appear similar to glass and can stimulate the stained glasses.

\section{XIX.STAINED GLASS}

Glass is a silicate. The overall stability of the glass depends on what elements are added and the precise quantities used. It is at the intial melting stage that colour is introduced. This usually takes the form of various metal oxides, which are either dissolved into the glass or applied on top of a clear sheet of glass.

\section{DETERIORATION IN STAINED GLASS}

There is both physical and chemical deterioration in stained glass. The physical damages include such factors as strong winds, hardened cement, bad fixing, faculty design of the structure, loss of paint due to bad fixing, vandalism etc. The chemical deterioration is due to the condensation of water on glass. If water is allowed to remain on the surface of glass for a prolonged period it attacks the glass by releasing the alkali metal icons forming the hydroxides. By this the glass will become weaker in structure and more likely to crack and deteriorate.

\section{XXI.CONSERVATION OF STAINED GLASS}

A detergent in deionised (is water that has had almost all of its mineral ions removed, such as cations like sodium, calcium, iron, and copper, and anions such as chloride and sulfate) water removes surface dirt. No water is left behind on the surface. In order to remove the cement used in the stained glass, the cement portion is soaked in a detergent solution. The accretions are removed by air abrasion by air sodium bicarbonate. The mended portions are cleaned with acetone. The corroded lead cames are replaced with new ones. Since glass is fragile, it is essential that good storage facilities should be used. Stable glass can be stored and displayed at normal ambient museum conditions.

\section{ORGANIC OBJECTS}

$\begin{array}{ll}\text { i) } & \text { Palm leaf Manuscripts } \\ \text { ii) } & \text { Textiles } \\ \text { iii) } & \text { Rubber Objects } \\ \text { iv) } & \text { Leather Objects } \\ \text { v) } & \text { Feather Objects }\end{array}$




\section{International Journal of Engineering Applied Sciences and Technology, 2019 Vol. 4, Issue 5, ISSN No. 2455-2143, Pages 390-400 \\ Published Online September 2019 in IJEAST (http://www.ijeast.com)}

\section{PALMLEAF MANUSCRIPTS}

In the tropical countries like India, China palm trees are in vogue and the palm leaves were used as writing materials. Styluses were used to inscribe on palm leaves. Museum, temples, libraries etc., are in possession ofpalm-leaf manuscripts, which consist of Stalapuranas, accounts, Ramayana, Mahabharaha, local history, medicine etc, should be preserved.

\section{PREPARATION OF PALM-LEAF MANUSCRIPTS}

The tender palm leaves of 4 to 5 weeks old are cut into required size and dried under shade or buried under marshy water. On the contrary, they are boiled in steam or in turmeric solution. Such seasoned palm leaves are inscribed by stylus. Since the inscribed letters are having the colour of the leaf the inscribed portions were either applied with the essence of Kadukkai (Terminalia chebula) or green leaves of Kovakkai plant (Coccinea grandis). The letters after sometimes appear black, making it legible to read. The palm-leaf manuscripts range from $4 \mathrm{~cm}$ to $85 \mathrm{~cm}$ in length and up to a bundle thickness of $50 \mathrm{cms}$. Sometimes the palm-leaves are found to have paintings. The edges of bundles are gold gilded.

\section{DETERIORATION OF PALM LEAF MANUSCRIPTS}

Palm-leaf manuscripts are organic in nature and therefore they are affected by high humidity, micro organisms, insects, dust, heat, mishandling, vandalism and ill maintenance. When certain insects attack them they bore holes from one edge to the other making a tunnel and hence the leaves are stuck together. The edges are accumulated with dust and they attract fungal attack. Normally the palm-leaf manuscripts were preserved in the lofts of the kitchen. They are accumulated with soot and smoke etc, eat away the surface and the letters are lost.

\section{CONSERVATION OF PALM LEAVES}

The stuck palm leaves of the bundles are baked in a steam vessel. Steam percolates and moistens the clayey materials and the leaves are easily separated. The leaves are cleaned with brush followed by rectified spirit. Then a $5 \%$ solution of citronella oil or lemon grass oil or olive oil in rectified spirit or the extract prepared out of fresh palm leaves in rectified spirit is applied and allowed to dry in shade. The oil used restores flexibility to the pail-leaf as the cells in the leaves absorb oil. If the palm- leaf is distorted 1:1 rectified spirit water mixtures is applied and pressed between oil papers and kept under weight. When dried it is found flat. Then $5 \%$ oil in spirit is applied and dried. This act not only gives flexibility but also provides insecticidal and fungicidal property to the palmleaf manuscripts.

\section{RESTORATION OF PALM-LEAF MANUSCRIPTS}

The broken palm-leaf manuscripts should be restored. The restoration can be done in many ways. Because of the cleaning process or natural means the letter become illegible. Therefore the inscribed portion is rubbed with Kadukkai essence, Kovai plant leaves or lampblack in oil. Then the mending is done. The torn portions are cut to the required size keeping similar inscribe leaf underneath with a knife. The affected portions are now pasted at the edges with the cut leaves using a $10 \%$ solution of poly vinyl acetone. At times lamination by chiffon using Maida flour paste is done. Lamination by cellulose acetate foil and acetone is also done but the edges are trimmed so that the leaves may breathe.

\section{TEXTILES}

There are references for the use of leaves and leather as dress materials. Barks of certain trees were also used to make clothes. When man learnt to spin and weave the fibres and fabrics came into existence. The term 'fibres' covers untreated leaves, grasses and reeds, as well as threads spun, twisted or plaited from any of these, plus asbestos, coconut husk, human and animal hair and the more familiar fibres like cotton, silk, linen, wool and modern synthetics. Fabrics are made by any of these fibres by weaving, or by non woven process such as knitting, lace making, and netting. The invention of dyes made man to make colored fabrics.

\section{CAUSES OF DETERIORATION}

\section{Biological Agents}

Micro organisms like fungi grow on textiles made of cotton, flax, hemp, jute, wool etc. fungi not only weaken the fibres but also leave stains, which are difficult to remove. Termites destroy all types of textiles. Wool-moths attack woolen materials. Certain beetles like the dermested beetles damage wool and silk. 


\section{International Journal of Engineering Applied Sciences and Technology, 2019 Vol. 4, Issue 5, ISSN No. 2455-2143, Pages 390-400 \\ Published Online September 2019 in IJEAST (http://www.ijeast.com)}

\section{Mishandling and Vandalism}

Improper display and storages cause greater damages to the textiles. Neglect and ill maintenance are one of the causes. Vandalism is yet another serious factor, which damages museum textiles.

\section{CONSERVATION OF TEXTILES}

Acidity in textiles makes them to change the colour and weakens the fibres. Acidity of the textiles is found out by $\mathrm{pH}$ (is a measure of the acidity). From the colour change one can find out the $\mathrm{pH}$ and say whether the textile is acidic or alkaline. If the textile is plain without any colour it may be de-acidified with ammonia in a closed chamber. In case of fast coloured fabric the acidity maybe removed by keeping the textile in between chiffon cloths on a glass support and washing with $1 \%$ Extran (Laboratory Detergents for Washing)in distilled water. It is thoroughly washed in water to remove acidity as well as the soap completely. Stains are removed by ringing method. The stained side is padded with cotton and from the other side a solvent like acetone is applied which loosens the stain and is absorbed by the cotton pad. In European countries wet methods of treatment is abandoned.

\section{RUBBER OBJECTS}

Museums at present collect objects of all types. In European countries present day objects are collected and displayed. Ethnographic museums collect objects of rubber. Rubber is present in the form of natural rubber bands, coloured balloons, tyres, inner tubes etc.

\section{Constituents of Rubber}

Natural rubber is prepared out of the latex from the rubber tree. Rubber is largely composed of unsaturated polymers like poly isoprene, polyputadiene, polystyrene and co-butadiene.

\section{CAUSES OF DETERIORATION}

Since rubber is an unsaturated chemical compound, it is susceptible to oxidation. When rubber is oxidized the product may be softened or hardened. Attack by ozone causes and subsequent cracking of the rubber objects. Prolonged and uncontrolled oxidation and attack by ozone results in disintegration of rubber and serious damage to objects.

\section{CONSERVATION MEASURES}

There are several measures, which are trying to protect rubber from its degradation. There are both physical and chemical methods.

\section{Physical Method}

Physical methods involve introducing a barrier between rubber and atmosphere i.e. giving a coating on the rubber or sealing the objects in a bag, which is oxygen proof. Coating of chemicals or resins will alter the appearance of the rubber objects.

\section{Chemical Method}

Chemical methods include keeping an oxygen free environment to rubber by keeping the rubber in a nitrogen atmosphere and the oxygen present may be absorbed by keeping Ageless, which is nothing but finely divided active iron, which forms iron oxides and hydroxides on absorption of oxygen. The materials which are considered to have suitable properties are poly vinylidene chloride film. The physical condition of the rubber objects may be monitored periodically by photography in order to see the change.

\section{XXXIV.LEATHER OBJECTS}

Leather is nothing but cured skin which is dehaired, defatted made non-putrescent and impervious to water. Skin is composed of three main layers.

1. Epidermis-outer layer

2. Corium or dermis-middle layer which the leather is made

3. Subcutaneous layer-the third layer.

Skin is a net work of protein fibres chiefly collagen. Tanning is a method of processing skin to produce leather. To convert a skin to leather it is usual to remove both the layers above and below the corium, which is then subjected to various treatments such as dehairing by liming, picking, tanning, splitting, dying, puffing etc.

\section{DETERIORATION OF LEATHER}

Leather is an organic material. High humidity, low humidity and temperature affect leather objects. High humidity encourages moulds growth and other biological activities. Low humidity dehydrates the leather objects there by leather gets hardened and embrittled. 


\section{International Journal of Engineering Applied Sciences and Technology, 2019 Vol. 4, Issue 5, ISSN No. 2455-2143, Pages 390-400 \\ Published Online September 2019 in IJEAST (http://www.ijeast.com)}

Dust and pollutants like sulphur dioxide make leather to receive acidity there by leather objects become brittle. Daylight and high level of artificial light affect leather adversely. They can cause fading and color change and accelerate deterioration.

\section{XXXVI.CONSERVATION MEASURES}

The environment should be controlled where the leather objects are displayed or stored. In the storage the leather objects should be kept covered by acid free tissue paper to avoid dust and sulphur dioxide. Three dimensional objects should be displayed or stored with their shapes supported. Metal pins or staples should never be used to fix leather objects to a mount. Leather objects should be fumigated with thymol or para dichloro benzene to avoid the biological activity in the objects. Hardened leather objects may be flexible by the application of $2 \%$ castor oil in rectified spirit. Fungal affected leather objects are fumigated and cleaned with a vacuum cleaner and treated with para nitro phenol in rectified spirit. Light intensity should be low in the gallery.

\section{FEATHER OBJECTS}

Feather forms art objects on their own rarely. They become part of an object such as head-dress, crown etc. they are almost always secured to some kind of substrates, such as netting, basketry and the method of attachment of the feathers may be sticking, tying etc. protein 'keratin' is the main constituent in feather. It is similar to that of hair but with a rather different molecular structure. Feathers are not flexible as hair but will break if folded or stretched.

\section{XXXVIII.CAUSES OF DETERIORATION}

Feather is inherently quick stable. And gradually they become brittle over a period of years. The bright yellow and red colours in the feather fade at higher levels of light. Feathers are susceptible to dust, which settles and become trapped. The dirt soil is appearance and provides an additional food source for insects and moulds. Insects attack feathers at larval stage, which feeds on keratin.

\section{CONSERVATION OF FEATHER WORK}

The dirt may be removed by brushing with soft brush using rectified spirit. The eggs of the insects may be removed by brushing. It is better to maintain the relative humidity (RH) between 45 and $60 \%$ and temperature between 20 to 22 Celsius. In case of coloured feathers, they should not expose above 100 lux (measurement). Dust should be avoided either by filtration or keeping the objects in showcases. Infected objects should be isolated and fumigated. Careful handling is important as feathers can be easily bent or broken, or the vanes disrupted. In handling such objects both the hands should be used. Folding should be avoided. Feather work should be stored in dark and cool areas with protection against dust. Open storage should be avoided. Handling objects while inspection should be avoided. Objects should be displayed within cases having light up to 100 lux.

\section{Storage}

Feather objects should be stored in dark, cool environment with protection against dust. They should be stored individually not heaped. Three dimensional objects should be well padded and supported to retain their shape. Open display of the feather objects is not advisable because of the dangers of moth, dust and physical damage, if they are touched by the members of the public.

\section{PAINTINGS}

I) Drawings, Prints and Paintings on Paper.

II) Thanjavur Paintings

III) Kalamkari Paintings

IV) Photographs

\section{DRAWINGS, PRINTS AND PAINTINGS ON PAPER}

Paintings are graphic designs on any support with pigments. Many materials like rock, wall, wood, bark etc were used as supports for executing paintings. Sketches, drawings were made on supports like cloth, wood etc. After the invention of printing press, prints were made available. After the invention of paper, it was used as a support for paintings, drawings and prints, paper boards were also used for these purposes.

\section{DETERIORATION TO PAPER PAINTINGS}

Moisture, heat, light, dust, insects are the various deteriorating agencies other than mishandling, faulty display, storage and neglect. Wrong choice of pigments also makes the 


\section{International Journal of Engineering Applied Sciences and Technology, 2019 Vol. 4, Issue 5, ISSN No. 2455-2143, Pages 390-400 \\ Published Online September 2019 in IJEAST (http://www.ijeast.com)}

paintings, drawings and prints to deteriorate. Keeping them in proper environment keeps the objects in good condition.

\section{CONSERVATION OF PAPER ART WORK}

White paper or paper- boards are changed to brown because of acidity present in the paper and atmosphere. Because of age, the surface gets accumulated dust, which obscures the look of the prints or paintings. They easily get stained. The stains are removed by fine eraser. Acidity from paper is removed by applying barium hydroxide (saturated solution) at the back of the print, very carefully. Vapour phase bleaching may be done in case moisture removes the pigments. When mending is required the inconspicuous corners of the paper print are taken and filled in the missing areas. Fragile paper works are chiffon laminated with maida flour paste added with insecticide and fungicide at the backside. The excess paste is very carefully squeezed out by a squeeze roller. When slightly dried under shade it is kept between blotting papers at the back and oil paper in the front and weight is placed over it. After it gets dried, it is taken out.

\section{THANJAVUR PAINTINGS}

The Thanjavur paintings are in the gilded (cover with gold, paint gold, lacquer gold, inlay with gold) and gem set techniques and are scared icons of the Hindu deities. The iconic style is therefore not an isolated phenomenon but is spread throughout the southern India and was practiced for about 200 years, approximately 1700-1900 A.D.

\section{PAINTINGS TECHNIQUE}

A sheet of cardboard is coated with tamarind seed paste (white of the seed with gum) to a jack tree wooden base, which is single or joined one. One or two cloths are pasted to the card board. A lime paste is coated, which is called sudhai and smoothened. Details are drawn and the positions where gemstones are to be set are marked. Sukkan (unboiled limestone ground with glue) is applied and the surrounding is raised with sukkan. Over the relief areas gold paper is cut into strips and pasted with tamarind seed paste. The gold work on Thanjavur painting is of two distinct varieties. Gold gilding is either with pure gold leaf or with gold paper.

\section{DAMAGES IN THANJAVUR PAINTINGS}

The Thanjavur paintings are composite in nature, the problems are also multiple. The wooden planks are joined, they give way due to age and cracking is noticed on the paint as well as the textile and cardboard support. The gold paper is lost due to insect attack. The space between the textile and plank are affected by insects and the cardboard is badly damaged. Loss of gemstones and cut glasses, which are used for ornamentation, are noticed. At times it is noticed that the paint applied on white gemstones are also lost due to abrasion. Loss of pigments is noticed. Wrinkling of the surface due to cleavage of support layers, water stain and fading of paints are noticed.

\section{CONSERVATION TREATMENT}

\section{Main Support}

The main support of the painting is fine cloth when there is some loose adhesion, tamarind seed paste is used to fix the textile with the accessory support.

\section{Accessory Support}

The fine cloth is normally pasted on a card-board which is in turn pasted to jack tree plank, which may be a sheer single plank or two planks joined together and reinforced by two or three reapers. The planks are set right and the cracks are filled with wooden putty.

\section{Frame}

Thanjavur paintings have a broad and light wooden frame. The bottom frame is sometimes broader than the other three sides. The plaster ornaments are repaired, if lost. The frames are cleaned, with fine emery and sprayed with a gild prepared out of gold gild power and resin in thinner. It gives a thinner look.

\section{Glass Front}

Thanjavur paintings are generally provided with glass fronts or with frames with provision for glass front. If there is no glass front, a $3 \mathrm{~mm}$ glass front is provided with a spacer in between the painted surface and glass.

\section{GENERAL CARE OF THANJAVUR PAINTINGS}

Thanjavur paintings should be periodically examined for their condition. 


\section{International Journal of Engineering Applied Sciences and Technology, 2019 Vol. 4, Issue 5, ISSN No. 2455-2143, Pages 390-400 \\ Published Online September 2019 in IJEAST (http://www.ijeast.com)}

Application of spray of insecticides is given at the plywood backing. It is better to fumigate the paintings in paradichlorobenzene to drive off any insect trapped inside the frame work.

\section{KALAMKARI PAINTINGS}

Kalamkari literally means done by pen (pen work). The art of painting on cloth with dyes is found in Gujarat. Andhra Pradesh and Tamil Nadu. The technique is a painstaking process using natural- vegetable and mineral dyes. Masulipatam work is also referred to as Kalamkari, it is strictly not pen work, for the outlines and main features of all the designs are printed with hand carved blocks, which are used repeatedly for years. The Kalamkari paintings of Kalahasti are painted temple hangings while the Masulipatam block printed fabrics have little religious association.

\section{DAMAGE}

Paintings on cloth are affected by insects, pests and micro-organisms like fungi, beetles etc. fading, staining, loss of materials and mechanical damages are common. Natural pollutants in the atmosphere cause acidity in paintings leading to browning and finally to brittleness of the thread. Cloth being good water absorbent absorbs the acid dissolved in the atmosphere and becomes acidic.

\section{CONSERVATION KALAMKARI PAINTINGS}

Fumigation is first carried out. Acidity is then removed with the help of ammonia fumes. Small tears are mended by different methods of darning using threads weaker than cloth. Holes are mended with spot lining with fabric. The fabric has to be of similar count as that of the original painting and dyed using natural colours. In some cases when the painting is in an extremely weak and fragile condition, darning is not advisable.

\section{PHOTOGRAPHS}

The art of photography came into existence in the $19^{\text {th }}$ Century. Museums preserve photographs, negatives, slides, cassettes etc. Therefore the information regarding the preservation and care of photographic materials are much useful to the curators or collectors of such materials.

\section{HISTORY OF PHOTOGRAPHIC MATERIALS}

In order to take measures to preserve photographs-positive, negative or slide- one must have knowledge to capture a photo. Photographic processes are of three groups namely silver-based, iron- based and chromium-based. Out of these the silver-based photographs are the famous ones. Paper was used as support, which could not give sharp images. Glass negative was used in 1847. Glass supports are now a days replaced by celluloid, cellulose nitrate or cellulose acetate or even latest by polyester film.

\section{DETERIORATION OF PHOTOGRAPHS}

Photograph is a very complex material, having several components like support, binding medium and photosensitive image forming chemical which may react in different ways to various factors of deterioration. The common deterioration noticed in photographs are yellowing, stains, separation of emulsion, fungal attack, insect attack, scratches, finger prints, folds etc. photographs fixed on moist walls have been affected by fungi.

\section{CONSERVATION PHOTOGRAPHS}

In case of glass negatives, due to age, the emulsion becomes brittle, cracks and falls off at slightest shock or touch. The gelatin is easily prone to damage by water, the negatives or photographs should never be touched on the face, and should be held at the edges. Photographs or negatives should never be kept together as they stick to each other in a humid condition and it is very difficult to separate them without damage. If the humidity is very low, the gelatin portion starts cracking. Micro-organisms like fungi affect the photographs at humid environment. Silver fish eats the gelatin as well as paper. It is an irreparable loss. While framing photographs the glass should never touch the photograph but spacer should be provided between the glass and the photograph.

\section{BOOKS FOR REFERNCE}

1. Siddique M.A, 2005 Architectural panorama of Chennai, (pp. 25-30)

2. Tony Bennett, 2013 The Birth of the Museum History, (pp.50-55)

3. Report of the Expert Committee for the Preservation of Antiquities in Government Buildings, Tamilnadu,1999,(pp.70-78) 
International Journal of Engineering Applied Sciences and Technology, 2019 Vol. 4, Issue 5, ISSN No. 2455-2143, Pages 390-400

Published Online September 2019 in IJEAST (http://www.ijeast.com)

4. Gravely F.H. and Ramachandran T.N., 2002 Catalogue of Hindu Metal Images in the Government Museum, (pp.100-110)

5. Srinivasa Desikan V.N., 1998 Guide to the Bronze Gallery, (pp.200-220) 